\title{
Chemical control of sorghum shoot tly: dosage, method and frequency of insecticide application in India
}

\author{
S. L. Taneja* and V. K. Henry \\ International Crops Research Institute for the Semi-Arid Tropics (ICRISAT), Patancheru PO, \\ Andhra Pradesh 502 324, India
}

\begin{abstract}
Experiments in resistant and susceptible sorghum genotypes during the post-rainy season from 1986 to 1988 at ICRISAT. India showed that foliar applications of cypermethrin applied by 'Electrodyn' sprayer were significantly superior to high-volume and low-volume sprays. Effective control of shoot fly and higher grain yields were obtained when the spray was initiated 6 days after crop emergence. The lowest dosige of cypermethrin (22.5 g a.i. ha ${ }^{-1}$ ) gave shoot fily control and grain yield increases similar to those of the higher dosages ( 33.75 and $45 \mathrm{~g}$ a.i. ha ${ }^{-1}$ ). Chemical control of shoot fly had the greatest effect on shoot fly infestation and increases in grain yields in susceptible genotype CSH 1, followed by the local M35-1 and resistant ICSV 707. Cypermethrin applied by Electrodyn was significantly superior to the recommended practice of carbofuran soil application and high-volume spray of endosulfan in reducing shoot fly damage in all the three genotypes. The main effect of eypermethrin foliar alpplication was in the reduction of shoot lly oviposition that resulted in less damage, indicating either an oviposition deterrent effect or death of the adulis betore oviposition.
\end{abstract}

Keywords Shoot fly; cypermethrin; 'Electrodyn' sprayer; Atherigona soccata; chemical control; oviposition deterrent; sorghum; application methods

\section{Introduction}

Shoot fly, Atherigona soccata Rondani, is an important pest of sorghum in Asia, Africa and Mediterranean Europe. It attacks sorghum in the seedling stage [5-25 days after emergence (DAE)] and causes deadhearts, resulting in poor plant stand and reduced grain yield. Its attack is very severe in late-sown crops, as well as in the second crop where two crops a year are taken. Soil application and seed treatment with carbofuran have been recommended for late sowings in the rainy season as well as for sorghum grown in the post-rainy season in India (Thimmaiah et al., 1973; Usman, 1973). However, the effectiveness of carbofuran is mainly dependent on soil moisture. In the post-rainy season, carbofuran does not give effective control where sorghum is grown on receding soil moisture. At ICRISAT, where host-plant resistance work is carried out against spotted stem borer, early infestation by shoot fly interferes with stem borer resistance screening. Soil application of carbofuran at sowing also adversely affects artificially released borer larvae in the plant whorls (Taneja and Leuschner, 1985).

Foliar applications of contact insecticides using conventional high-volume sprayers were not effective in the control of shoot fly (Vedamoorthy et al., 1965; AICSIP, 1969: Chachoria, 1972; Meksongsec, 1972); this was attri-

"To whom correspondence should be addressed buted to poor insecticide coverage on the undersurface of leaves. The new technology of electrodynamic spraying using a hand-held battery-operated 'Electrodyn' (registered Trade Mark, ICI Agrochemicals) sprayer produced electrically charged small droplets accurately deposited over most of the target surfaces (Coffee, 1981). The Electrodyn sprayer was extensively tested for shoot hy control in sorghum during the 1986-1988 post-rainy seasons.

\section{Materials and methods}

Experiments were conducted during the post-rainy seasons in black soil (vertisols) regarding method of insecticide application, dose of inseeticide and control elficacy on shoot fly-resistant and -susceptible sorghum genotypes.

\section{Application method}

Shoot fly-susceptible genotype CSH 1 was sown on 25 September 1986 in rows $75 \mathrm{~cm}$ apart. The experiment was laid out in al randomized complete block design with 20 treatments and three replications. The plot size was eight rows of $6 \mathrm{~m}\left(6 \times 6 \mathrm{~m}^{2}\right)$. Thinning was carried out 1 day before the first spray, i.e. 5 days after crop emergence (DAE), maintaining $10 \mathrm{~cm}$ spacing between plants. Three methods of foliar spray application were tested: Electrodyn 
Table 1. Effect of foliar application of cypermethrin on shoot fly damage and grain yield in sorghum, post-rainy season, 1986

\begin{tabular}{|c|c|c|c|c|c|c|}
\hline \multirow{2}{*}{$\begin{array}{l}\text { Spraying } \\
\text { ecuiptuent }\end{array}$} & \multirow{2}{*}{$\begin{array}{l}\text { Time of } \\
\text { applicition } \\
(\mathrm{DAE})^{u}\end{array}$} & \multicolumn{2}{|c|}{ Percentage plants with slioot fly } & \multicolumn{2}{|c|}{ No. of panicles per plot } & \multirow{2}{*}{$\begin{array}{c}\text { Grain yield } \\
(\mathrm{kg} \text { ha }\end{array}$} \\
\hline & & Eggs & Deadhearts & Main & Total & \\
\hline \multirow[t]{6}{*}{ Electrodyn } & 6 & $9(16.0)^{\circ}$ & $8(15.5)^{\circ}$ & $1.38(4.878)^{d}$ & $16.3(5.069)^{d}$ & 1544 \\
\hline & 6 and 12 & $9(15.5)$ & $8(14.8)$ & $161(5.052)$ & $188(5.205)$ & 1729 \\
\hline & 6,12 and 18 & $6(12.9)$ & $5(12,6)$ & $220(5.392)$ & $234(5.449)$ & 1757 \\
\hline & 12 & $45(+1.9)$ & $+2(40.5)$ & $99(4.528)$ & $184(5.205)$ & 1240 \\
\hline & 12 and 18 & $36(36.1)$ & $32(34,0)$ & $114(4.723)$ & $186(5.217)$ & 1331 \\
\hline & 18 & $64(54.3)$ & $66(54.1)$ & $67(4.038)$ & $153(+.967)$ & 1094 \\
\hline \multirow[t]{6}{*}{ High volume } & 6 & $18\{23.8\}$ & $18(23.1)$ & $187(5.211)$ & $223(5.392)$ & 1236 \\
\hline & 6 and 12 & $16(22.4)$ & $19(26,0)$ & $157(5.044)$ & $193(5.252)$ & 1174 \\
\hline & 6,12 and 18 & $14(20.9)$ & $15(22.1)$ & $157(5.0+1)$ & $172(5.127)$ & 1306 \\
\hline & 12 & $+3(41.1)$ & $40(39.3)$ & $126(4.762)$ & $242(5.473)$ & 1089 \\
\hline & 12 and 18 & $30(31.8)$ & $34(35.5)$ & $147(4.900)$ & $228(5.428)$ & 1034 \\
\hline & 18 & $50(45.2)$ & $56(48.6)$ & $86(4 .+45)$ & $182(5.193)$ & 956 \\
\hline \multirow[t]{6}{*}{ Low volume } & 6 & $4](39.6)$ & $42(40.1)$ & $126(4.642)$ & $168(5.016)$ & 928 \\
\hline & 6 and 12 & $39(38.6)$ & $37(37.4)$ & $181(5.174)$ & $241(5.469)$ & 924 \\
\hline & 6,12 and 18 & $46(42.3)$ & $4+(41.2)$ & $119(4.659)$ & $186(5.208)$ & 1052 \\
\hline & 12 & $45(42.1)$ & $43(39.8)$ & $93(4.498)$ & $147(4.965)$ & 893 \\
\hline & 12 and 38 & $53(47.0)$ & $52(45.7)$ & $103(4.617)$ & $211(5.335)$ & 929 \\
\hline & 18 & $58(49.6)$ & $58(48.9)$ & $54(3.946)$ & $106(4.6[3)$ & 8.37 \\
\hline Carboluran al sowing & & $62(52,3)$ & $62(50.8)$ & $66(4.074)$ & $187(5.171)$ & 947 \\
\hline Untreated eleck & & $60(51.2)$ & $61(50.4)$ & $59(4.073)$ & $159(5.0+5)$ & 760 \\
\hline s.e.n. (t) & & $(4.48)$ & $(4.28)$ & $(0.2933)$ & $(0.2366)$ & 167 \\
\hline$C V(10)^{\circ}$ & & $(31)$ & $(31)$ & (8) & (6) & 18 \\
\hline
\end{tabular}

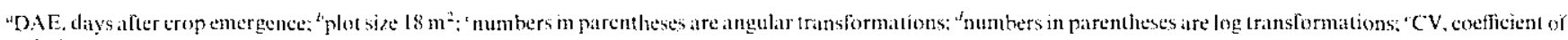
variatlion

[3 electrochargeable liquid (ED), $750 \mathrm{ml}$ ha" ${ }^{1}$ ], high volume (2001 ha- $\left.{ }^{-1}\right)$ using a knapsack sprayer, and low volume $\left(15 / \mathrm{ha}^{-1}\right.$ ) using a spinning-disc sprayer. Soil application of carbofuran $\left(1.2 \mathrm{~kg}\right.$ a.i. ha $\left.{ }^{-1}\right)$ and untreated plots served as checks. A synthetic pyrethroid. cypermethrin ( $45 \mathrm{~g}$ a.i. ha ${ }^{-1}$ ) was applied as a foliar treatment once (6. 12 or 18 DAE), twice (6 and 12 DAE or 12 and 18 DAE) or thrice $(6,12$, and $18 \mathrm{DAE})$, using the three methods of spraying. The crop was maintained on receding soil moisture without irrigation.

\section{Insecticide dosage}

During 1987. shoot fly-susceptible genotype CSH 1 wats sown on 30 September in rows $75 \mathrm{~cm}$ apart. Thinning was carried out as described carlier. Three doses $(22.5,33.75$ and $45 \mathrm{ga}$ i. hal ${ }^{-1}$ ) of the insecticide cypermethrin were applied with the Electrodyn sprayer. The frequencies of application were once ( 6 DAE), twice ( 6 and 12 DAE) and thrice (6.12 and 18 DAE): thus there were 10 treatments, including an untreated check, with three replications. The plot size was eight rows of $6 \mathrm{~m}\left(6 \times 6 \mathrm{~m}^{2}\right)$.

\section{Chemical control and resistant genotypes}

During the 1988 post-rainy season, three genotypes (susceptible CSH 1, local variety M35-1, and shoot fiyresistant ICSV 707) were planted on 5 October in rows $75 \mathrm{~cm}$ apart. The experiment was laid out in al split-plot design with genotypes as main treatments and insecticide application as sub-treatments. There were 6 subtreatments: cypermethrin (22.5 g a.i. ha ${ }^{-1}$ ) applied by an Electrodyn sprayer once (at 6 DAE) and twice (at 6 and 12 DAE); endosulfan ( $350 \mathrm{~g}$ a.i. ha ${ }^{-1}$ ) applied by a knaspsack sprayer, once (at $6 \mathrm{DAE}$ ) and twice (at 6 and $12 \mathrm{DAE}$ ): carbofuran soil application (1.2 $\mathrm{kg}$ a.i. ha $\left.{ }^{-1}\right)$ and an untreated check. The sub-plot size was eight rows of $9 \mathrm{~m}$ $\left(6 \times 9 \mathrm{~m}^{2}\right)$, with three replications.

$i$ In all three experiments, observations on shoot fly oviposition were made 14 and 21 DAE and deadheart counts at 21 and $28 \mathrm{DAE}$. Observations were taken from the central two rows in each plot, in which all the plants and those with shoot fly eggs and deadhearts were counted to give the percentages of plants with eggs or deadhearts. At harvest, main stem panicles and tiller panicles were harvested separately from the central four rows in each plot, sun-dried and threshed. The grain yield wals calculated on a per hectare basis and subjected to statistical analysis.

\section{Results and discussion}

\section{Application method}

The effect of foliar application of cypermethrin on shoot fly damage and grain yield during the 1986 post-rainy crop season is given in Table 1. Shoot fly egg laying was significantly lower when cypermethrin was applied using an Electrodyn at 6 DAE. 6 and 12 DAE and 6,12 and 18 DAE: however, it did not differ significantly from high- 
volume spraying at the same times of application. The other treatments had more egg laying and did not differ from carbofuran and the untreated check. Egg laying was significantly increased when the first spray was applied at 12 DAE or later, indicating that spraying in the early growth stage (6 DAE) is essential to reduce egg laying. Among the foliar applications, the low-volume spray treatment had the maximum oviposition, indicating the ineffectiveness of this treatment in reducing shoot fly oviposition.

Deadhearts caused by shoot fly infestation were least when plants were sprayed by the Electrodyn in treatments that included the application $6 \mathrm{DAE}$. There was no difference in damage after one, two or three applications within application methods, provided that the treatment 6 DAE was included. However, in treatments where the treatment $6 \mathrm{DAE}$ was omitted, even the Electrodyn spray did not reduce shoot fly damage. With the high-volume spray, shoot fly damage was reduced when the application 6 DAE was included, but damage reduction was not equal to that brought about by the Electrodyn spray. Two applications of low-volume spray at 6 and 12 DAE resulted in significantly lower infestation than the untreated check; however, it was significantly higher than that after the Electrodyn application, when the treatment $6 \mathrm{DAE}$ was included. The low-volume spray resulted in poor coverage of the target surfaces, whereas the charged sprays improved deposition on the undersurface of leaves (Sharp, Bals and Villalba, 1986), which is the preferred site for oviposition. After hatching, the larva migrates to the leaf whorl, from where it penetrates down towards the growing tip. Inadequate insecticide coverage of the leaf and stem may result in poor and ineffective treatment. The main effect of the chemical application was on oviposition, as significantly less damage was recorded only in those treatments where oviposition was significantly low. This implies that chemical application either acted as an oviposition deterrent for the females, or the females were killed by the chemical action before they could lay the eggs. The failure of shoot fly control with foliar application of contact insecticides, even when started 4 days after crop emergence and repeated at weekly intervals (Yatham, 1967; AICSIP, 1969; Chachoria, 1972; Meksongsee, 1972), may be due to poor coverage of the undersurface of leaves by the high-volume sprays used by these workers.

Although soil application of carbofuran granules has been reported to give satisfactory control of shoot fly (Barry, 1972; Meksongsee, 1972; Kundu and Sharma, 1975; Srivastava and Jotwani, 1981; Sukhani and Jotwani, 1982), it did not reduce shoot fly damage in the study described, here, perhaps because of soil moisture and soil type. In the trial, the crop was raised in the post-rainy season on receding soil moisture in black soil; no rainfall was received during the growing period and supplementary irrigation was not given. Carbofuran uptake by plants largely depends on soil moisture, and this might not have been adequate.

Main panicle production was significantly higher in six treatments with low shoot fly damage (Electrodyn 6 and 12 $\mathrm{DAE}$, and 6, 12 and $18 \mathrm{DAE}$; high volume $6 \mathrm{DAE}, 6$ and 12
DAE, and 6,12 and 18 DAE; and low volume 6 and 12 DAE) but lower in treatments with high shoot fly damage (Table 1). However, total panicle production, main plant and tillers combined, did not differ significantly between treatments. Shoot fly damage caused tiller production, which contributed to the total grain yield; however, the grain yield from tillers was lower than that from the main plants.

Grain yields in five insecticide treatments (Electrodyn 6 DAE, 6 and 12 DAE, 6, 12 and 18 DAE, and 12 and 18 DAE, and high volume 6 and 12 DAE) were significantly higher than the untreated check. Compared with carbofuran, only the first three treatments gave significantly higher yields (Table 1). There was no significant difference in grain yield among these five treatments. This means that only one application of cypermethrin at 6 DAE adequately reduced shoot fly damage, resulting in an increased grain yield. This may not hold true when the fly population is very high and more than one application would be required for effective control.

\section{Insecticide dosage}

All three dosages of cypermethrin $(22.5,33.75$ and $45 \mathrm{~g}$ a.i. ha $^{-1}$ ) applied with the Electrodyn sprayer resulted in reduced oviposition, although not significantly so (Table 2). Insecticide dosage and frequency of application (once, twice or thrice) did not result in significant differences in oviposition. The lowest shoot fly damage (deadhearts) was recorded with three applications of cypermethrin $(6,12$ and $18 \mathrm{DAE})$ at the highest dosage ( $45 \mathrm{~g}$ a.i. ha ${ }^{-1}$ ), although it did not differ significantly from the results of two and three applications of either dosage. Although one application (6 DAE) resulted in significantly higher damage than two or three applications, this damage was significantly less than that in the untreated check. All the insecticidal concentrations tested in this trial significantly reduced shoot fly damage compared with the untreated check; however, the differences between these treatments were not significant. The highest and lowest dosages gave similar control.

Numbers of main panicles were significantly higher in plots treated three times with the highest and the lowest dosages, compared with the untreated check. However, the total number of panicles did not differ significantly between the treatments. The maximum grain yield was recorded after three applications of the highest dosage $(45 \mathrm{~g}$ a.i. $\mathrm{a}^{-1}$ ), which was significantly higher than the untreated check and one application of insecticide (Table 2). A progressive reduction in grain yield was observed as the number of insecticide applications was reduced from three to one; however, this reduction was not significant.

\section{Chemical control and resistant genotypes}

The susceptible genotype CSH 1 suffered the maximum shoot fly oviposition and damage when untreated, followed by the local genotype M 35-1 and resistant ICSV 
Table 2. Effect of foliar application of cypermethrin on shoot fly damage and grain yield in sorghum, post-rainy season, 1987

\begin{tabular}{|c|c|c|c|c|c|c|}
\hline \multirow[b]{2}{*}{$\begin{array}{l}\text { Dose } \\
\text { (g. al.i. hal " })\end{array}$} & \multirow{2}{*}{$\begin{array}{l}\text { Time of } \\
\text { application } \\
\text { (DAE) }\end{array}$} & \multicolumn{2}{|c|}{ Percentage plants with shoot fly } & \multicolumn{2}{|c|}{ No. of pinicles per plot } & \multirow[b]{2}{*}{$\begin{array}{l}\text { Griin yield } \\
\text { (kg ha" 1) }\end{array}$} \\
\hline & & Egges & Deildheirts & Main & Totil & \\
\hline 22.5 & $\begin{array}{l}6 \\
6 \text { and } 12 \\
6,12 \text { and } 18\end{array}$ & $\begin{array}{l}18(24.5)^{\circ} \\
13(21.1) \\
15(22.2)\end{array}$ & $\begin{array}{r}19(26.0\}^{\circ} \\
7(14.9) \\
5(12.7)\end{array}$ & $\begin{array}{l}139(4.923)^{d} \\
153(4.975) \\
186(5.226)\end{array}$ & $\begin{array}{l}173(5.1 .49)^{2} \\
171(5.084) \\
203(5.314)\end{array}$ & $\begin{array}{l}2239 \\
2724 \\
3032\end{array}$ \\
\hline 33.75 & $\begin{array}{l}6 \\
6 \text { and } 12 \\
6,12 \text { and } 18\end{array}$ & $\begin{array}{l}20(24.9) \\
23(26.3) \\
16(23.2)\end{array}$ & $\begin{array}{r}21(27.3) \\
6(13.6) \\
12(20.2)\end{array}$ & $\begin{array}{l}138(4.923) \\
158(5.047) \\
158(5.060)\end{array}$ & $\begin{array}{l}196(5.272) \\
185(5.216) \\
184(5.2[2)\end{array}$ & $\begin{array}{l}2485 \\
2842 \\
3068\end{array}$ \\
\hline 45 & $\begin{array}{l}6 \\
6 \text { and } 12 \\
6,12 \text { and } 18\end{array}$ & $\begin{array}{l}13(20.6) \\
15(21.7) \\
18(24.3)\end{array}$ & $\begin{array}{r}20(26.6) \\
6(13.0) \\
3(8.4)\end{array}$ & $\begin{array}{l}140(4.935) \\
169(5.123) \\
193(5.245)\end{array}$ & $\begin{array}{l}179(5.175) \\
185(5.216) \\
216(5.359)\end{array}$ & $\begin{array}{l}2287 \\
2968 \\
3566\end{array}$ \\
\hline Untrested cheek & & $32(34.2)$ & $45(42.1)$ & $109(4.679)$ & $185(5.2 \geq 0)$ & 1885 \\
\hline $\begin{array}{l}\text { s.e.m.(st) } \\
\text { CV }(0 \%)^{\circ}\end{array}$ & & $\begin{array}{l}(6.5) \\
(33)\end{array}$ & $\begin{array}{l}(4.2) \\
(27)\end{array}$ & $\begin{array}{l}(0.1644) \\
(4)\end{array}$ & $\begin{array}{l}(0.1377) \\
(3)\end{array}$ & $\begin{array}{c}415 \\
18\end{array}$ \\
\hline
\end{tabular}

"As in Tihl" I

Table 3. Effect of chemical application on shoot fly damage and grain yield in sorghum, post-rainy season, 1988

\begin{tabular}{|c|c|c|c|c|c|c|c|}
\hline \multirow[b]{2}{*}{ Genotype } & \multicolumn{2}{|c|}{ Cypermethrin (DAE) ${ }^{a}$} & \multicolumn{2}{|c|}{ Endosullan (DAE) } & \multirow{2}{*}{$\begin{array}{l}\text { Carbofuran } \\
\text { soil appli- } \\
\text { cation }\end{array}$} & \multirow{2}{*}{$\begin{array}{l}\text { Untreated } \\
\text { check }\end{array}$} & \multirow[b]{2}{*}{ Mean } \\
\hline & 6 & 6,12 . & 6 & 6,12 & & & \\
\hline \multicolumn{8}{|l|}{ Oripostion $(0 ; 0)$} \\
\hline $\begin{array}{l}\text { CSH 1 } \\
\text { M 35-1 } \\
\text { ICSV } 707 \\
\text { Mean }\end{array}$ & $\begin{array}{l}31(33.7)^{r} \\
25(29.8) \\
17(23.5) \\
24(29.0)\end{array}$ & $\begin{array}{l}27(31.0) \\
22(77.9) \\
12(20.7) \\
20(26.4)\end{array}$ & $\begin{array}{l}74(59.4) \\
49(44.5) \\
25(29.7) \\
49(44.5)\end{array}$ & $\begin{array}{l}69(56.5) \\
45(42.2) \\
24(29.1) \\
46(42.6)\end{array}$ & $\begin{array}{l}97(74.4) \\
71(57.4) \\
39(38.7) \\
67(56.8)\end{array}$ & $\begin{array}{l}87(69.9) \\
68(55.3) \\
40(39.0) \\
65(54.7)\end{array}$ & $\begin{array}{l}63(54.2) \\
47(42.8) \\
26(30.0)\end{array}$ \\
\hline \multicolumn{8}{|l|}{ Deadhearts $(\%)$} \\
\hline $\begin{array}{l}\text { CSH I } \\
\text { M } 35-1 \\
\text { ISCV } 707 \\
\text { Mean }\end{array}$ & $\begin{array}{l}19(25.5)^{r} \\
19(24.9) \\
12(19.4) \\
16(23.3)\end{array}$ & $\begin{array}{r}15(22.4) \\
17(23.9) \\
9(17.2) \\
13(21.2)\end{array}$ & $\begin{array}{l}63(52.3) \\
43(40.9) \\
23(28.5) \\
43(40.6)\end{array}$ & $\begin{array}{l}57(49.1) \\
39(38.7) \\
23(28.2) \\
40(38.7)\end{array}$ & $\begin{array}{l}68(55.8) \\
53(46.5) \\
30(33.0) \\
50(45.1)\end{array}$ & $\begin{array}{l}91(73.9) \\
64(53.3) \\
43(41.2) \\
66(56.2)\end{array}$ & $\begin{array}{l}52(46.5) \\
39(38.0) \\
23(27.9)\end{array}$ \\
\hline \multicolumn{8}{|l|}{ Malin panicles (per plot)" } \\
\hline $\begin{array}{l}\text { CHS } 1 \\
\text { M } 35-1 \\
\text { ICSV } 707 \\
\text { Mein }\end{array}$ & $\begin{array}{l}237(5.466)^{\prime \prime} \\
142(4.784) \\
137(4.808) \\
172(5.019)\end{array}$ & $\begin{array}{l}244(5.497) \\
164(4.935) \\
157(4.976) \\
188(5.136)\end{array}$ & $\begin{array}{l}161(5.072) \\
132(4.662) \\
123(4.727) \\
139(4.821)\end{array}$ & $\begin{array}{l}193(5.252) \\
144(4.787) \\
128(4.841) \\
155(4.960)\end{array}$ & $\begin{array}{l}205(5.305) \\
163(4.982) \\
149(4.969) \\
172(5.085)\end{array}$ & $\begin{array}{l}162(5.071) \\
156(4.928) \\
100(4.596) \\
139(4.865)\end{array}$ & $\begin{array}{l}201(5.277) \\
150(4.846) \\
132(4.820)\end{array}$ \\
\hline \multicolumn{8}{|l|}{ Total panicles (per plot)" } \\
\hline $\begin{array}{l}\text { CSH } 1 \\
\text { M } 35-1 \\
\text { ICSV } 707 \\
\text { Mean }\end{array}$ & $\begin{array}{l}314(5.745)^{d} \\
181(5.070) \\
212(5.298) \\
236(5.371)\end{array}$ & $\begin{array}{l}336(5.8(5) \\
192(5.155) \\
232(5.432) \\
253(4.467)\end{array}$ & $\begin{array}{l}772(5.594) \\
154(4.845) \\
188(5.161) \\
705(5.200)\end{array}$ & $\begin{array}{l}306(5.722) \\
167(4.992) \\
197(5.278) \\
233(5.331)\end{array}$ & $\begin{array}{l}308(5.724) \\
207(5.271) \\
201(5.283) \\
239(5.426)\end{array}$ & $\begin{array}{l}259(5.546) \\
203(5.240) \\
152(5.019) \\
205(5.268)\end{array}$ & $\begin{array}{l}799(5.691) \\
184\left(5.0^{4} 6\right) \\
{[97(5.245)}\end{array}$ \\
\hline \multicolumn{8}{|l|}{ Grain yield ( $\mathrm{kg}$ ha ${ }^{\prime}$ ) } \\
\hline $\begin{array}{l}\text { CSH } 1 \\
\text { M35-1 } \\
\text { ICSV } 707 \\
\text { Mein }\end{array}$ & $\begin{array}{l}3792 \\
1600 \\
2166 \\
2519\end{array}$ & $\begin{array}{l}3879 \\
1910 \\
3172 \\
2987\end{array}$ & $\begin{array}{l}2797 \\
1295 \\
2447 \\
2180\end{array}$ & $\begin{array}{l}3192 \\
1601 \\
2651 \\
2482\end{array}$ & $\begin{array}{l}3421 \\
1775 \\
{[124} \\
2440\end{array}$ & $\begin{array}{l}3003 \\
1619 \\
2032 \\
2218\end{array}$ & $\begin{array}{l}33.47 \\
1633 \\
2432\end{array}$ \\
\hline $\begin{array}{l}\text { s.e.m. }( \pm) \text { for } \\
\text { Genotype } \\
\text { Treatment } \\
\text { Genotype } \times \text { Treatment } \\
\text { CV }(\%)^{4}\end{array}$ & & 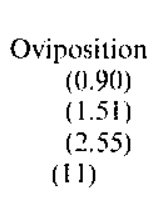 & $\begin{array}{l}\text { Deiadhearts } \\
\qquad \begin{array}{r}(1.44) \\
(1.43) \\
(2.69) \\
(11)\end{array}\end{array}$ & $\begin{array}{l}\text { Main } \\
\text { panicles } \\
\begin{aligned}(0.1592) \\
(0.0992) \\
(0.2335) \\
(6)\end{aligned}\end{array}$ & $\begin{array}{l}\text { Total } \\
\text { panicles } \\
\begin{array}{l}(0.1361) \\
(0.0800) \\
(0.1858) \\
(5)\end{array}\end{array}$ & $\begin{array}{l}\text { Grilin yis]d } \\
105.1 \\
115.6 \\
210.9 \\
14\end{array}$ & \\
\hline
\end{tabular}

"As in Table $l$; plot size $27 \mathrm{~m}^{3}$; "As in Tablel

707 (Table 3). A similar trend was observed in all treatments with cypermethrin, endosulfan and carbofuran.

Foliar application of insecticide significantly reduced shoot fly oviposition when compared with the untreated check and carbofuran soil application; however, the damage was significantly lower in all the treatments, including carbofuran (Table 3). The least oviposition and damage was observed in plots treated with cypermethrin once or twice. The reduction in the oviposition and damage, as a result of chemical application, was greatest in 
the susceptible genotype CSH I and least in the resistant ICSV 707.

The number of main panicles did not differ significantly between genotypes. nor between insecticidal treatments. Plots treated twice with cypermethrin produced significantly more panicles than the untrated check in CSH 1. Total panicle numbers did not differ significantly between the genotypes or between insecticidal treatments. A significantly higher grain yield was recorded in CSH 1, followed by ICSV 707 and M 35-1 (Table 3). Among the treatments. cypermethrin applied twice recorded a significantly higher grain yield than all other treatments. The grain yield in other treatments did not differ significantly from the untreated check.

Three seasons' data show the effectiveness of cypermethrin foliar application using the Elect rodyn sprayer, in shoot fly control. However, effective control is obtained only when the first insecticide application is made within the first week after crop emergence. This one spray is sufficient for shoot fly control in moderately resistant genotypes, but a second application of insecticide a wetk later is required for susceptible genotypes, and in high shoot fly populations. Soil application of carbofuran and foliar application of endosulfan could not control shoot lly effectively in the post-rainy season. The main effect of cypermethrin foliar application was in the reduction of oviposition, resulting in lower damage. This implies that the chemical application acted either as an oviposition deterrent for the adult hies, or the females were killed before laying eggs. However, there was also some toxic effect of the insecticide, as evident from the 1987 and 1988 trials.

\section{Notes and acknowledgements}

The authors are grateful to $\mathrm{Mr} \mathrm{A}$. Narasimha and $\mathrm{Mr} \mathrm{K}$. Hareendernath of Cereals Entomology for assistance and to Dr K. F. Nwanze for his critical comments on the manuscript.

Approved as J. A. No. 1324 by the International Crops Research Institute for the Semi-Arid Tropies (ICRISAT), Patancheru, A.P. 502324 , India.

\section{Ref́erences}

AICSIP (1969) .tll Fulia Cordinated Sorghtm Improvement Project Progress Report 1969. Indian Council of Agricultural Research and Cooperative Agencies, Hyderabatú, India

Barry, D. (1972) Chemical control ol sorghum shoot fly on a susceptible varixty of sorglum in Ugandia. J. Econ. Entomol. 65. 1123-1125

Chachoria, H. S. (1972) Control ol shoot fly will insecticide spray and large scale trial in India. In: Control of Sorghtm Shoot $\%$ ly (Fd. by M. (i. Jotwatui and W. R. Young) pp. 274 286, Oxlord and IBH Company. Delhi

Coffee, R. A. (1981) Electrodynamic crop spraying. Outl fgric. 10. $350 \cdots 356$

Kundu, G. G. and Sharma, J. K. (1975) Ellicacy and compatibility in soil application of some systemic insecticides in the eontrol of sorghum shoot fly, therigona soccata Rond. Indiat J. Entomol. 37, 230,233

Meksongsee, B. (1972) Chemical control of shoot fly in Thailand. In: Control of Sorghm Shon Fly (Ed. by M. G. Jotwani and W. R. Young). pp. 241-251. Oxlord and IBH Company, Delli

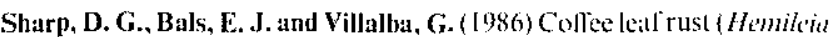
vartatrix Berk, and Вr.) in Colombiat 11. Low volume application -droplet deposition and the implications for machine design. Proc. 1986 Br. Crop Prot. Comf. Pests Dis. 385-39?

Srivastava, K. P. and Jotwani, M. G. ([98]) Efficacy of granular insecticides for the control of shoot fly. Entomologists News/ent 6. $58-59$

Sukhani, T. R. and Jotwani, M. G. (1982) Spol treatment of granular insecticides for the control of sorghum shoot lly, ftherigonat socerat (Rondani). Indian J. Entomol. 44, 117-120

'Taneja, S. L. and Leuschner, K. (1985) Methods of rearing, inlestittion. and evaluation for (hilo patcllas resistance in sorghum. In: Proc. Im. Sorghm Entomologl Workshop, 15-2l Julv 1964. Toxas at a Universitr, Colloge Station, Texas, USA. pp. 175-188, International Crops Rescarch Institute for the Semi-Arid Tropics, Pattancheru. India

Thimmaiah, G., Panchabhavi, K. S., Desai, K. S. M., Usman, S. and Kajjari, N. B. (1973) Chemical control of sorghum shoot lly ( $1 \mathrm{t} / \mathrm{h}$ rigont raria soccala Rondani (Diplerat: Antlomytidite) in Mysore State. Inlikm J. Agric. Sci. 43, 29)4-298

Usman, S. (1973) Elficacy of granular insecticide for sorglum shoot lly control. In: Control of Sorghm Shoot Fly (Ed. by M. G. Jotwani and W. R. Young), pp. 252-261, Oxford and IBH Company, Delhi

Vedamoorlly, G., Thobbi, V. V., Matai, B. H. and Young, W. R. (1965) Preliminary studies with seed and seed furrow atpplication ol insecticides lor the control of the sorghum stem maggot, Atherigona india $\mathrm{M}$. (Anthomyidate) Indian $J$. Agric. Sci. 35, 14-28

Yatham, S. (1967) Eflect ol irrigation on the efficicy of soil treatment with granular systemic insecticides against the sorghum shoot fly. Atherigona raria (R). Israd J. Enomol. 2, 171 175

Received 9 March 1992

Revised 7 June 199?

Accepted 9 June 1992 